\title{
Rubber Stretches Over Two Anniversaries
}

Life got much easier for children at play a century ago this year. In 1888 in Belfast John Boyd Dunlop, a successful Scottish veterinarian, invented the pneumatic tire to provide a more comfortable ride for his son's tricycle. Dunlop tested his tire in Great Britain in 1888 and in the United States in 1890 . The smoother ride of airfilled tires instead of the previous solid rubber ones helped bring about the cycling craze of the 1890s.

After Dunlop's patent was issued, it was discovered that the principle of the pneumatic tire had already been patented in 1846, but Dunlop held enough accessory patents to keep his company going successfully, though he never did make a fortune from his invention. He sold the company along with his patent in 1896.

Rubber will be celebrating another important anniversary next year -150 years ago, in 1839, Charles Goodyear discovered the vulcanization process by spilling a mixture of rubber latex and sulfur on a hot stove. Vulcanization made rubber into the useful, durable material familiar to everyone today.

Rubber had been used centuries earlier in the New World. When Christopher Columbus returned from Haiti, he supposedly brought back rubber balls that he had seen the Indians bouncing against a tree. (This account was written more than 100 years after Columbus returned, so some historians doubt its authenticity.) Other Spanish explorers later learned how the South American Indians made waterproof shoes by smearing the milky white latex from rubber trees on their feet and allowing it to dry. They also made rubber bottles in much the same way...spreading the latex over a clay form and, when the latex had hardened, washing away the clay from the inside.

In 1735, the explorer Charles Marie de La Condamine-who had been commissioned by the Academy of Science of Paris to measure a degree of the meridian in South America-sent back to France hardened latex samples from Peru. The English chemist Joseph Priestley (better known as the discoverer of oxygen) noticed in 1770 that balls of the hardened latex could be used to rub out pencil marks...from this we get the name "rubber."

Liquid latex couldn't be shipped back across the ocean since it would dry out on the voyage. Instead, crude masses of hardened raw rubber were shipped in cakes or balls. Once the shipments reached Europe, the problem was how to manipulate the rubber into a more desirable form. Two Frenchmen, surgeon L.A.P. Herissant and chemist Pierre Joseph Macquet, introduced the use of turpentine and pure ether as solvents for the hardened latex. Using their technique, they were able to make some of the first rubber surgical instruments.

Others soon discovered that this solution of latex and turpentine-rubber cement-could make a waterproof cloth. In 1823 Scottish chemist Charles Macintosh began producing his famous raincoats, misspelled as "mackintoshes," that consisted of two layers of cloth coated with the rubber cement solution and then sandwiched together. Macintosh introduced coal-tar naphtha as a more effective solvent than turpentine or ether.

Macintosh's partner, English inventor Thomas Hancock, continued to work with raw rubber, sure that "something must eventually be done with so singular a substance." Hancock patented the idea of applying strips of rubber directly to cloth (in 1820) since his first attempts to coat fabrics with the turpentine/latex solution did not result in a satisfactory texture-and they smelled bad. Hancock also invented a machine called a "masticator" that allowed the reprocessing of scrap rubber.

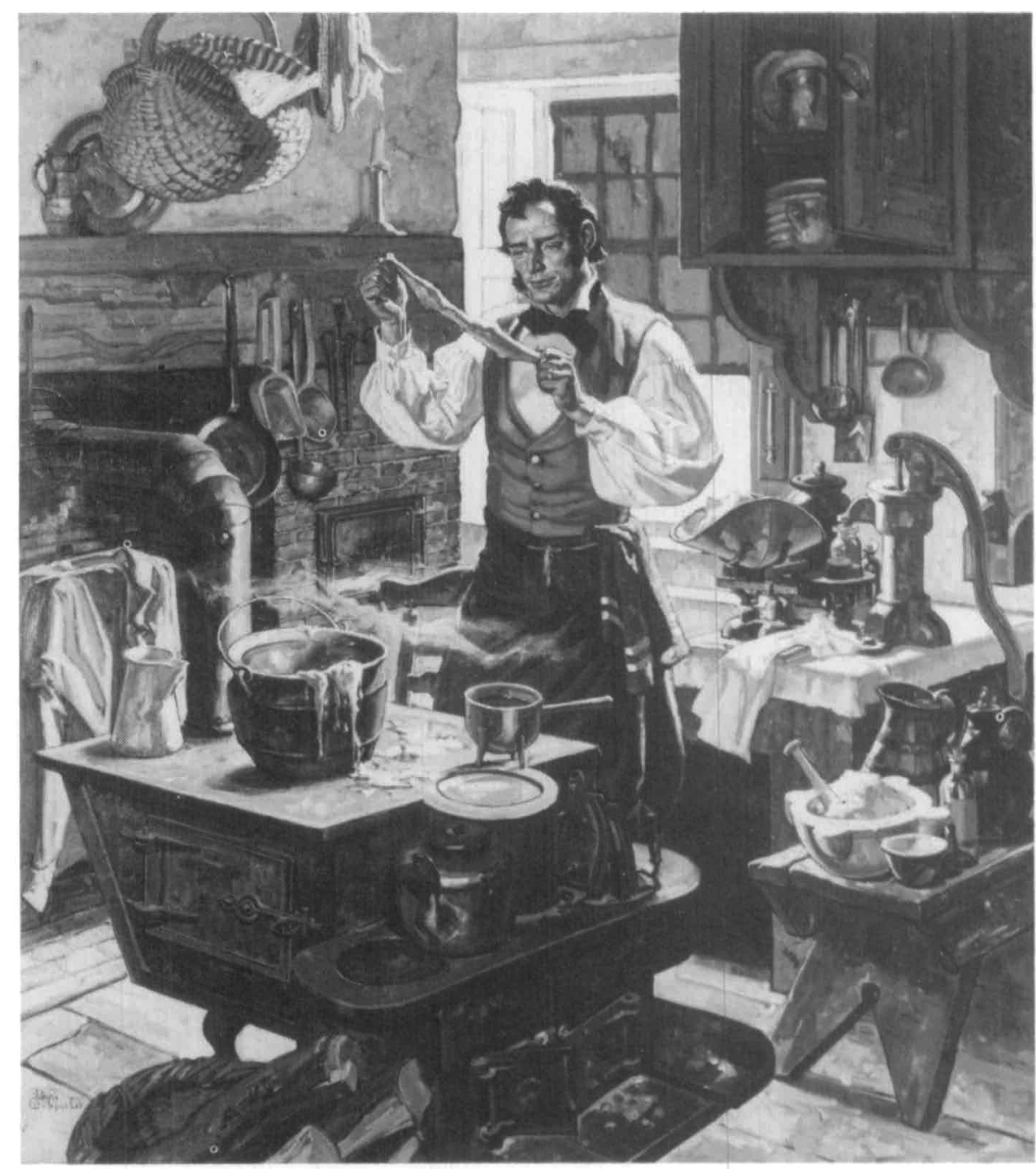

In 1839 Charles Goodyear discovered the vulcanization process by spilling a mixture of rubber latex and sulfur on a hot stove. Illustration courtesy of Goodyear Tire $\mathcal{E}$ Rubber Co. 

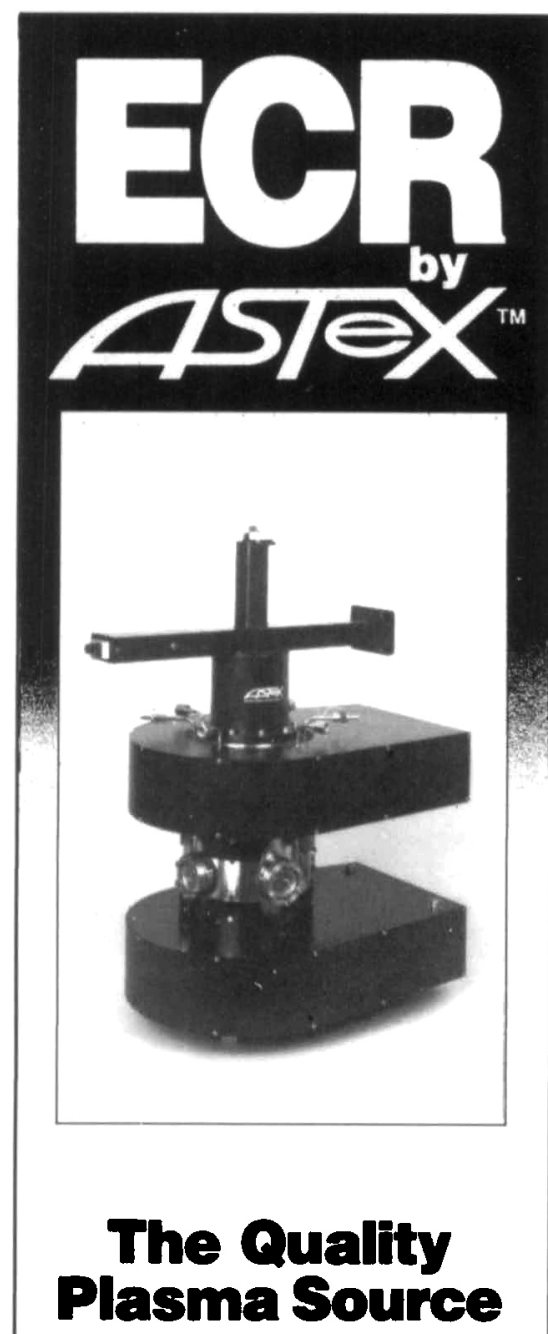

Unique symmetric plasma microwave coupler $\triangle$ UHV compatible double-walled stainless plasma chamber - Includes ASTEX S-1000 microwave power supply with exceptional output quality (with regulation to $0.1 \%$ and ripple less than $1 \%$ ) for reliable processing Ideal high current replacement in ion beam applications, provides low energy ion stream, compatible with any reactive gas for diamond-like coatings, sputter and ion assisted deposition, and etching

An extensive line of quality microwave plasma systems is available. Call for details. 617-876-5545

Applied Science and Technology, Inc. 40 Allston Street Cambridge, MA 02139
But natural rubber had a severe problem-it softened and flowed when it got too hot, and it hardened and cracked when it grew too cold. Following Macintosh's success and improving on Hancock's masticator machine, new manufacturing techniques aboundedbut they reached the material limits of natural rubber until the substance itself could somehow be improved. Natural rubber could not be used in many industrial applications, or even in the cold and heat of everyday seasonal fluctuations in the United States and Great Britain. The rubber became tacky, it had an unpleasant smell, and it degraded easily.

Then in 1839 the American Charles Goodyear discovered the vulcanization process. Goodyear was the son of an inventor of farm implements. He and his father went into the hardware business together but went bankrupt in 1830, and Charles Goodyear was thrown in debtor's prison in 1834. While in prison, he began to think about how valuable a material rubber could be if it didn't get hard in cold weather and sticky in warm weather. Though he wasn't a chemist, nor did he have any clear idea of what might work, he conducted his first experiments while still in prison, trying anything and everything until he found a technique that worked. He continued experimenting until his death in 1860 .

In 1836 he found a process of treating the rubber with nitric acid. The idea looked promising and he secured a contract with the U.S. government to manufacture mailbags. The venture did not prove successful.

A year later he joined forces with $\mathrm{Na}$ thaniel Hayward, who had worked with a rubber company and had proposed a process of using sulfur to "dry" rubber. The process didn't work particularly well, but Goodyear bought the right to use it from Hayward anyway. Goodyear was working with a mixture of rubber, sulfur, lead, and other chemicals when he spilled it on a hot stove. The addition of heat did the trick- "vulcanizing" the rubber, allowing the sulfur to act as a crosslinking agent for the polymer strands. The resulting rubber didn't melt as he expected...in fact, it proved far more durable than any rubber he had ever seen

The rubber industry had been centered primarily on waterproofing clothes (in Great Britain) and on making rubber overshoes (in the United States), but with Goodyear's new durable rubber, the industry could find mechanical applications, such as bicycle tires and machinery.
Trying to raise interest in his process (and to generate capital for further research), Goodyear sent samples of his vulcanized rubber to England. Thomas Hancock, Macintosh's business partner, obtained some of the samples and became obsessed with learning the process that had so remarkably improved the material's utility. For nearly four years Hancock worked on his own to discover what Goodyear had done.

[N]atural rubber had a severe problem-it softened and flowed when it got too hot, and it hardened and cracked when it grew too cold.

Meanwhile, Goodyear, in poor health and dogged by creditors, finally got around to filing for his British patent in 1844-one year after Hancock had discovered a similar (and less effective) process that didn't require lead. Thus began the first of many patent-infringement battles -60 in all. Charles Goodyear was to fight for the rest of his life.

Once the vulcanization process became widely known, it became nearly impossible to enforce patent restrictions because the technique itself was so simple. Goodyear spent most of his time fighting legal battles, but he did not win his case until 1852, with Daniel Webster acting as his lawyer.

Goodyear traveled widely to promote his vulcanization process, trying to generate capital. French Emperor Napoleon III awarded him the Legion of Honor, but that didn't get him any money. He fell deeper into debt, spent more time in a debtor's prison (this time in France) and finally died in 1860 , owing more money than he ever had in his life-somewhere between $\$ 200,000$ and $\$ 600,000$.

Unfortunately for Goodyear, the greatest use of his vulcanized rubber-in automobile tires-did not come about until 50 years after his death. Most of today's needs are filled by synthetic rubbers, other elastomers with similar (and sometimes superior) material properties. But like John Boyd Dunlop, Goodyear's legacy lives on with his name on our automobile tires and his seminal work embodied in the corporation bearing his name.

KEVIN J. ANDERSON 